\title{
Rural sustainability and food choice: the effect of territorial characteristics on the consumers' preferences for organic lentils
}

\author{
Chiara Paffarini ${ }^{1}$, Biancamaria Torquati ${ }^{i^{*}}$ (D, Tiziano Tempesta ${ }^{2}$, Sonia Venanzi ${ }^{1}$ and Daniel Vecchiato ${ }^{2}$
}

\author{
* Correspondence: bianca.torquati@ \\ unipg.it \\ ${ }^{1}$ Department of Agricultural, Food \\ and Environmental Sciences, \\ University of Perugia, Borgo XX \\ Giugno 74, 06121 Perugia, Italy \\ Full list of author information is \\ available at the end of the article
}

\begin{abstract}
The importance of pulse cultivation and consumption is recognized by the scientific community in terms of human nutrition, food security, biodiversity and a valid substitute for animal protein. In some marginal areas, pulse cultivation represents also a protection against the abandonment of agricultural land, the preservation of traditional landscape and the maintenance of natural environments, besides contributing to the safeguard of traditional gastronomy and culture.

This study explores how some characteristics connected with rural sustainability, like the preservation of the traditional rural landscape, production area in a Natura 2000 Site of Community Importance (SCI) and EU quality labels (PDO and PGI), might influence organic consumers' choice of lentils. Data were collected in the Umbria region (Italy) in 2014 by interviewing 213 consumers' members of Organic Solidarity Purchase Groups (O-SPGs). The Discrete Choice Experiment methodology was used, and three different models (Multinomial Logit Model (MNL), Mixed Logit Model (RPL) and Endogenous Attribute Attendance (EAA)) were applied to verify the reliability of the estimates. Attribute non-attendance (ANA) behaviour was taken into account. Results reveal that the presence of ANA had an impact on both the relative importance of the estimated attributes and the magnitude of the estimated mean WTP. Therefore, this study suggests that WTP mean estimates should be considered with caution for marketing purposes if ANA is not considered. Looking at pulses, the results help to understand the importance in monetary terms of the relationship between lentil choice and rural sustainability.
\end{abstract}

Keywords: Traditional rural landscape, Natura 2000 SCls, PDO, PGl, Choice experiment, Attribute non-attendance

\section{Introduction}

With the declaration of 2016 as "International Year of Pulses" (IYP) and recognition of 10 February as World Pulses Day, both by the United Nations General Assembly (Eurostat, 2020), pulses have been given a central role in improving food security and nutrition and creating more sustainable and climate-resilient food systems (Curran et al., 2017; Xipsiti et al., 2017; Calles, 2016). Being pulses an essential nourishing food source in the low- and middle-income countries (LMICs) as well as part of their

(c) The Author(s). 2021 Open Access This article is licensed under a Creative Commons Attribution 4.0 International License, which permits use, sharing, adaptation, distribution and reproduction in any medium or format, as long as you give appropriate credit to the original author(s) and the source, provide a link to the Creative Commons licence, and indicate if changes were made. The images or other third party material in this article are included in the article's Creative Commons licence, unless indicated otherwise in a credit line to the material. If material is not included in the article's Creative Commons licence and your intended use is not permitted by statutory regulation or exceeds the permitted use, you will need to obtain permission directly from the copyright holder. To view a copy of this licence, visit http://creativecommons.org/licenses/by/4.0/. 
traditional dietary component, however, nutritional and environmental pulse value is still underestimated and average consumption remains low in Western Europe (Xipsiti et al., 2017): it is estimated between 7 and $8 \mathrm{~g} /$ capita/day (FAOSTAT, 2016) comparing with the nutritional recommendations that range up to 20-35 g/capita/day (Marlett et al., 2002).

Pulse production has grown globally since the early 1960s in all the world's regions (92.4 million tons in 2019). Between 1998 and 2018, pulse production increased 63\%. On the basis of continents, the highest pulse production in 2019 was in Asia (with an increase of 17.3 million tons over the past two decades) followed by sub-Saharan Africa (with a rise of 10.5 million tons in the same period) and America (with a gain of 7 million tons) (FAOSTAT, 2020). Moreover, even if the estimates suggest a growing world trade of pulses, there is still limited market information currently available on these products.

Conversely to world trends, the European production has decreased during the past two decades: Europe's share of global production declined from 20.1 to 8.8\% (Joshi and Rao, 2016). The latest data (2018) show that in European farming systems area devoted to the cultivation of pulses was 2170 thousand hectares producing 4110 thousand tonnes (Eurostat, 2020, FAO, 2019).

In terms of trade, the EU is a net importer of pulses, and lentils in particular, due to an insufficient domestic production (Eurostat, 2017).

The most produced pulses all over the world are dry beans following by chickpeas, dry peas, cowpeas and lentils. Concerning lentils, in 2019, the world annual production was about 5.7 million tonnes and about 4.8 million hectares of land were under this pulse globally. From 1994 to 2019, lentils globally increased by $+39 \%$ in production and over 100\% in yield quantities, being cultivated principally in Canada, India and Turkey (FAOSTAT, 2020).

Lentil consumption habits are different in the EU countries, due to regional food habits and traditions: the Mediterranean countries, in particular Spain, but also France, Italy and Greece, lead the consumption. Europe is a relatively small producer of lentils: in 2019, the production volume was 124,756 tons, but its share is growing. Around $90 \%$ of European production volume occurs in Spain and France (FAOSTAT, 2020).

Among the Mediterranean countries, Italy is a traditional producer of lentils. This pulse cultivated, thanks to an optimal combination of climate, soil and moisture of some Italian regions, in ancient times has provided a cheap source of dietary proteins to rural and urban families (Piergiovanni, 2000). In the last 50 years, the lentil quickly disappeared from favourable areas, being restricted to marginal, hilly and mountainous areas. As the lentil market became more competitive at the international level, lentils from other countries especially Canada started flooding the Italian market at very low prices, transforming Italy from being an exporter to be a net importer of lentils (Piergiovanni, 2000). However, the latest available data show that the Italian lentil area cultivated has increased by 65\% from 2011 to 2016 and, at the same time, the production has increased by $83 \%$ (FAOSTAT, 2018). Equally per capita Italian consumption has gradually increased: from $0.54 \mathrm{~g} / \mathrm{capita} /$ day in 1961 to $1.64 \mathrm{~g} /$ capita/day in 2015 (Confagricoltura, 2016) due to different factors. Firstly, lentils have been seen to play an important role in health-improving and disease-preventing (Takruri and Issa, 2013; Bouchenak \& Lamri-Senhadji, 2013; Afshin et al., 2014). Consumers are more 
interested in a healthy and sustainable diet (Hoek et al., 2017), and their involvement in environmental and social responsibility is leading to a rapid growth of the organic lentil sector (CBI, 2015). Understanding these consumers and their behaviours could increase their consumption sustaining and growing the pulse industry (Curran, 2017). Secondly, lentils are an essential instrument ensuring nitrogen balance in the soil, especially in no-livestock systems that always present a deficit in nitrogen availability (David et al., 2005) and their potential contribution to the mitigation of climate change (Jensen et al., 2012). Last but not least, the promotion of specific varieties recognized by the European Union quality label (Protected Designation of Origin (PDO) and Protected Geographical Indication (PGI)) has increased the consumer interest versus high-quality production $^{1}$.

Despite the exposed previous characteristics, in terms of benefits associated both with consumes of pulses (and lentils) and with environmental responsibility (as pulse cultivations reduce greenhouse gas emissions and help reduce animal-based consumption) (Magrini et al., 2018), the current literature on food consumer demand has never analysed preferences for lentils or organic lentils in Europe associated with the particular territorial characteristics of the production areas.

For partially filling the gaps found in the existing literature, we applied a Discrete Choice Experiment (DCE) to analyse consumers' preferences and willingness to pay (WTP) for organic lentils. The originality of our work lies in the understanding if particular territorial characteristics of the area of production (being part of a Natura 2000 $\mathrm{SCI}$, the presence of a traditional rural landscape, or the EU quality labels-PDO and PGI) are considered important by consumers while purchasing organic lentils. A further aspect of originality lies in the data analysis approach that took into consideration the effect of respondents not considering all attributes present in the DCE (attribute non-attendance (ANA)). We applied ANA behaviour because different food choice experiment studies have underlined that the food attributes used to describe the profile of the products throughout assessing the alternatives' set in a choice task could be neglected by survey respondents (Caputo et al., 2018). As far as we know, this is one of the few papers (Caputo et al., 2013; Scarpa et al., 2013; Bello and Abdulai, 2016) that considered ANA when applying DCE in the food sector (Caputo et al., 2018).

We focused on consumers' preferences of Organic Solidarity Purchase Groups' (OSPGs) members with the aim to investigate which attributes might influence their purchase of organic lentils basing on two considerations: (i) Italian lentil production is carried out on organic or low-input farms located in rural and fringe area and (ii) O-SPGs' members are generally considered "community-oriented conscious consumers" (Zoll et al., 2018, pg. 107) and, therefore, they should be the most responsive to this type of survey.

The paper is organized as follows: the "Theoretical background" section presents the study theoretical background; the "Material and methods" section focuses on the presentation of the DCE methodology, experimental design, questionnaire design, consumer sample selected and data collection. In the "Results" section, we present the

${ }^{1}$ At this moment, six specific lentils were recognized by the EU quality label: two are Italian, two are French and two are Spanish lentils. In Italy, the PGI-labelled Lenticchia di Castelluccio di Norcia was recognized in 1997, while the PGI-labelled Lenticchia di Altamura was recognized in 2017. The PGI-labelled Lenticchia di Castelluccio di Norcia is cultivated in a SCI area. 
results, and the discussion and conclusion are presented in the "Discussion and conclusions" section.

\section{Theoretical background}

Concerning lentils, few studies have examined consumer's preferences for this product to the best of our knowledge: Ariyawardana et al. (2012) have examined the consumer preferences for red lentils in Sri Lanka and how these preferences differ across shopping channels and by socio-demographic factors using a Conjoint Analysis approach. The results have shown that the consumers consider more important the visual quality than the other attributes (size, packaging and price). Govindasamy et al. (2014) have analysed the consumer preferences for the country of origin of lentils in Sri Lanka using a logit model. The results have shown that consumers with a high income per month are more likely to consider the country of origin as an important factor while purchasing red lentils. Recently, Warne et al. (2019) analysed the producers and consumer perceptions of the sustainability profile (in terms of environmental, socioeconomic and health dimensions) of the lentil system in the USA; applying multiplechoice, Likert-scale and open-ended questions, they report that consumers include their willingness to increase lentil consumption based on environmental (78\%), economic (75\%) and health and nutrition (72\%) information of lentils.

In Italy, the organic lentil production is carried out in rural marginal, hilly and mountainous areas with particular environmental landscape value; in some cases, these productions have also been recognized by EU quality labels (PGI). All these elements, if incorporated in the food product and recognized by consumers as values, can be related to rural sustainability. In fact, aiming at the general enhancement in the human condition, rural sustainability could be defined as continuous research for development strategies maintaining and producing rural communities that should tend to be "healthy". In such as rural communities, there are balances between economic, sociocultural, political and environmental values and at the same time they "respond to any imperatives in these dimensions, at least in the long run" (Bryant and Granjon, 2009, p. 162).

Considering the evolution in time of knowledge and comprehension of economic, socio-cultural, political and environmental values and of a change in production systems, in consumer behaviour and community awareness, rural sustainability is considered a social construction and an ongoing process and, hence, its research is a dynamic one. Hence, sustainability in agriculture is not only a goal to be achieved but also a process (Buttel, 2006; Marques et al., 2012; Darnhofer, 2015).

In these terms, the natural socio-economic development that brings consequently the needs of the populations will evolve and, therefore, the rural sustainability strategies should consider the changes that occur. For example, it is natural that people's choices evolve towards more sensitive choices than their own lives when they are able to satisfy some of their needs and when their vision of their world and that of others changes (Bryant and Granjon, 2009).

Investigating the interaction and the influence between the quality of the traditional rural landscapes throughout the world and food production-consumption is considered a fundamental matter for sustainable development by the international community. It is recognized that the landscape can correlate the different aspects (culture, agriculture, 
food production, environment and tourism) that are territory characteristic (Magnaghi, 2010) and, in these terms, the connection between landscape, food and territorial history holds particular meaning in case of quality food productions (Roe, 2016). This results crucial for traditional rural landscapes that are of particular interest because of their historical and cultural value and their beauty giving the area unique characteristics and identity (Agnoletti, 2013; Antrop, 2005; Claval, 2005; Howley et al., 2012; Torquati et al., 2015; Torquati et al., 2017). Examining vineyard landscapes, Camaioni et al. (2016) have reaffirmed the importance of quality in connection to both food and landscape; in fact, they underlined that the connection producer-consumer support can encourage a more sustainable territorial economic development because of being more attentive to the quality and identity of places and the rural communities. Some studies carried out in Italy highlighted that the quality of the landscape can influence consumer preferences and their willingness to pay a premium price for the produces obtained preserving the traditional landscape (Tempesta et al., 2010; Tempesta et al., 2014; Tempesta and Vecchiato, 2019; Torquati et al., 2018; Troiano et al., 2016).

In line with the concept that sustainability is an ongoing process and that environmental sustainability and quality are becoming ever more important for life quality and economic enhancement of the territory, protected areas such as Natura 2000 Sites of Community Importance (SCIs) can be a tool for successful sustainable rural development especially in economically lagging areas (Bastian et al., 2010). The high nature value areas such as Natura 2000 SCIs have the potential to become a driver concept in the European model of agriculture by its multifunctional characteristics and its contribution to the diversity and sustainability of rural areas and through the conservation of biodiversity (Peneva et al., 2015). Different studies (European Commission, 2018; Kettunen, et al., 2009) have tried to examine the management of farms in Natura 2000 SCIs looking for ways to accommodate farming and conservation objectives; the principal aim is underlining that in the many cases they are actualized win-win strategies which respect the nature but also maintain the economic viability of the farmers involved and provide valuable services to society. The productions in Natura 2000 Sites have the potential to be marketed under an "environmentally friendly" product label to capitalize on the growing consumer demand for sustainable goods (Kettunen et al., 2009; European Commission, 2013). In fact, the increased consumer demand for sustainably and biodiversity-friendly products contributes to also increasing opportunities to develop food markets for labelled products from or associated with protected areas such as Natura 2000 areas network.

In addition to that, the farmers could take profit to the customer's trend to increasing very keen on purchasing locally sourced food and to willing to pay extra for this characteristic (Carpio \& Isengildina-Massa, 2009; Darby et al., 2008; Giraud et al., 2005; Hébert, 2011; Loureiro \& Hine, 2002).

Several authors affirm that rural sustainability, implemented by the biodiversity preservation, landscapes and traditional knowledge, may be supported by the Geographical Indication (GI) protection (like EU quality labels PDO, PGI and TSG) (more recently: Bowen and Zapata, 2009; Lamarque and Lambin, 2015; Ricchieri et al., 2007; Vakoufaris, 2010) Barham, 2002; Guerra, 2004; Rangnekar, 2004; Williams and Penker, 2009; 
Giovannucci et al., 2009; Belletti et al., 2017a). In fact, GIs are considered a tool at the international level to maintain multi-functionality in rural landscapes; involve local populations in biodiversity management, land use and landscape conservation (environmental sustainability) (Belletti and Marescotti, 2011; Vandecandelaere et al., 2009; Belletti et al., 2015); and preserve local and traditional knowledge and practice, favouring local actor cohesion, empowerment and inclusion (social sustainability) (Bérard and Marchenay, 2006; Belletti and Marescotti, 2011). From the economic side, several authors (Bramley and Biénabe, 2013; Babcock \& Clemens, 2004; Bardhi \& Kapaj, 2017; Barjolle et al., 2007; Barjolle and Sylvander, 2000; 2011; Larson, 2007; Bowen, 2008; Colinet et al., 2006; Belletti et al., 2017a) specified that GIs promote rural sustainability in terms of to obtain premium prices for products and at the same time to guarantee safety and quality to consumers, to improve redistribution of the added value to the actors (producers, processors, etc.) throughout the production chain and to bring added value to the region of origin increasing local jobs (economic sustainability) (Belletti and Marescotti, 2011).

This is particularly true in marginalized rural areas where the infrastructural, structural, geographical and cultural matters do not allow easy to achieve economic survival and community as a consequence. In addition, the rural areas' crisis may expose to danger their local economies determining negative effects on the quality of both environment and social wellbeing and cause territorial culture and traditions loss. In this sense, GIs are an important protection tool fostering sustainable rural development, "provided that it is inserted in a wider and coherent network of actors and actions" (Belletti et al., 2017b, p. 274).

\section{Material and methods}

\section{The Discrete Choice Experiment methodology}

In recent years, the Discrete Choice Experiment (DCE) methodology became among the stated preference methods (Brown, 2003), one of the most widely used for the analysis of consumers' preferences of food products (Van Loo et al., 2011; Cantillo et al., 2020; Louviere et al., 2000; Ortega et al., 2011; Gracia, 2014; Marian et al., 2014).

The DCE methodology (Ben-Akiva et al., 2019; Hauber et al., 2016; Hensher et al., 2005) usually consists in presenting respondents a set of choice options (choice set) among which they are requested to choose their preferred one. Each choice option is characterized by a set of attributes or product characteristics, and each characteristic can assume different levels. For example, an attribute can be the price of the good, and its levels are the different amount of money $(1 € ; 2 €$; etc.) that are necessary to buy such good. While the price attribute is numeric, attributes can also be qualitative, like for example the "production method", and its levels in this case can be "organic" or "conventional". In this respect, each choice set presents a certain number of choice options that share the same attributes, but with different attribute levels.

Under the assumption that consumers make their choices rationally in order to maximize their utility (Luce, 1959; Thurstone, 1927), observing the choices made by respondents, it is then possible to indirectly derive how each attribute level 
contributes to respondents' utility: using other words, the importance of each attribute in determining the consumer probability of choice of a given product. The latter aspect is consistent with Lancastrian consumer theory (Lancaster, 1966) that postulates that a good or service utility is given by the sum of the utilities of its characteristics.

DCE is applied to study consumer preferences to collect information on three main aspects:

i) The WTP of respondents for the attributes analysed

ii) The relative importance of attributes for respondents

iii) The probability of success (namely choice) of a product, depending on its attribute levels

The WTP for each $i$ th attribute can be computed as the negative of the ratio between the estimated coefficient $\left(\beta_{i}\right)$ of the $i$ th attribute and the coefficient of the monetary attribute $\left(\beta_{\text {price }}\right)$ as explained in Eq. 1 .

$$
W T P_{i}=-\frac{\beta_{i}}{\beta_{\text {price }}}
$$

It is possible that respondents do not always take into consideration all attributes proposed in the DCE when making choices in a choice set. This situation is known in the literature as attribute non-attendance (ANA) (Hensher et al., 2012). If ANA occurs, respondents do not trade-off among the attribute levels presented in the study. This might be due to heuristics adopted by respondents in order to ease the decision process (Gilovich et al., 2002). Not taking into account ANA during data analysis might have serious consequences on the reliability of the estimates both in terms of market share predictions and welfare measures (Scarpa et al., 2013). Therefore, we decided to take ANA into consideration in our data analysis, and the latter was structured following two steps: first, we applied a mixed logit model (RPL) (Train, 2009) that considered the sample heterogeneity in preferences neglecting the potential presence of ANA; second, we applied Hole (2011) endogenous attribute attendance model (EAA) that considers ANA endogenously. There are two main approaches to detect ANA: the first-stated ANA-directly asks respondents if they took into consideration the attributes included in the DCE design; the second, inferred or endogenous attribute attendance (EAA), can be modelled endogenously (Hole, 2011; Scarpa et al., 2009). With respect to stated ANA, EAA has the advantage of reducing fatigue of the respondents that are not subject to extra questions about "attendance" in the questionnaire and to avoid the problem of the reliability of the answers given about attribute attendance. Given such advantages, we decided to rely on Hole (2011) EAA model to check the reliability of our RPL model results. A Multinomial Logit Model (McFadden, 1974) was estimated for completeness and comparison purposes despite it does not consider respondents' heterogeneity and ANA.

In applying the three models, we used a linear and additive utility function (Eq. 2): 


$$
\begin{aligned}
U\left(X_{i}\right)= & \beta_{A S C} \times A S C+\beta_{S C I} \times S C I+\beta_{P D O} \times P D O+\beta_{T R A D L} \times T R A D L \\
& +\beta_{P R I C E} \times P R I C E
\end{aligned}
$$

where ASC is a dummy variable assuming the value 1 if the choice option is the nobuy option ("none of these") and 0 otherwise ${ }^{2}, \mathrm{SCI}$ is a dummy variable assuming the value 1 if the proposed good is produced in a Natura 2000 SCI, PDO is a dummy variable assuming the value 1 if the product is characterized by a EU quality label (PDO or PGI), TRADL is a dummy variable assuming the value 1 if the lentils are produced in an area characterized by traditional rural landscape, and PRICE is a continuous variable for the attribute price.

DCE data were analysed using Stata version 16, and the models were estimated using the mixlogit (Hole, 2007) and eealogit (Hole, 2011) modules.

In our questionnaire, we included some "control questions" in order to check if respondents considered all of the proposed attributes and therefore made the necessary trade-offs among them. In order to check for attribute attendance, we used stated attribute attendance, and in particular a "serial approach" (Caputo et al., 2018). In the serial approach, respondents are requested to declare the attributes they attended at the end of the full set of choice tasks ( 3 in our case), while in the "choice task approach" they are requested to state which attributes they attended after each choice task.

\section{Discrete Choice Experiment design}

We used an "unlabelled" DCE design where four attributes were considered: two are strictly related to the territorial characteristics of organic lentils area production, one is a proxy for territorial quality and the last one is the price of the product (Table 1).

The two territorial attributes are the location of the production area in a Natura 2000 SCI and the presence of a well-preserved traditional rural landscape. The Natura 2000 SCIs act as a proxy for the natural quality of the place, while the traditional rural landscape acts as a proxy for the cultural identity and visual beauty of the place of production. The third attribute considered is the EU quality label (PDO or PGI) that can be considered a proxy for the quality of production. The price attribute was expressed as $€ / 500 \mathrm{~g}$ package of lentils. Basing on the previous price analysis of organic lentils sold through the AFNs at a premium price of $+30 \%$ with respect to conventional ones, three price levels $(3.79 € / 500 \mathrm{~g} ; 4.99 € / 500 \mathrm{~g} ; 6.19 € / 500 \mathrm{~g})$ were chosen for the survey (Table 1 ).

The choice sets presented to the respondents were obtained with an unlabelled $D_{\mathrm{p}}$-efficient design (Rose \& Bliemer, 2009) using Ngene software. It consisted of 6 choice sets, with 2 choice options each and a "none-of-these" option. The design was blocked into 2 blocks, and therefore, we presented 3 choice sets to each respondent. Figure 1 shows one of the choice tasks used during the data collection.

Data were collected with a questionnaire that consisted of an introductory part and three sections. The introductory part presented the survey and the institutions involved in the study, stressed the importance of participating in the survey and assured respondents that their answers would remain anonymous. A box insert

${ }^{2}$ This is motivated by our experimental design that is "unlabelled". While dealing with unlabelled designs that include a status-quo or no-choice option, it is necessary to include the effect of not choosing in the utility function specification with a dummy variable (ASC in our case). See Hensher et al. (2005), Appendix 10A "Handling unlabelled experiments" pg. 371, for an in-depth explanation of such requirement. 
Table 1 Choice experiment attributes and levels

\begin{tabular}{ll}
\hline Attributes & Levels \\
\hline Located in a traditional rural landscape & Yes/no \\
Located in Natura $2000 \mathrm{SCl}$ & Yes/no \\
EU quality label (PDO or PGI) & Present/absent \\
Price $(€ / 500 \mathrm{~g})$ & $3.79 ; 4.99 ; 6.19$ \\
\hline
\end{tabular}

summarized the research topic in simple language. In particular, interviewees were provided some information about the meaning and the importance of the traditional rural landscape and the Natura 2000 SCIs; interviewees were provided also the meaning of the EU quality labels for PDO and PGI. While introducing respondents to the meaning of the traditional rural landscape in the DCE scenario introduction, we drew upon Antrop's delineation of a "well preserved traditional rural landscape": "It contains the complex history of a place or region, which still can be read from its composition and structure" (Antrop, 2005, p.25). While introducing respondents to the meaning of the Natura 2000 SCIs, we drew upon the European Commission definition as reported on its website: "Natura 2000 is a network of core breeding and resting sites for rare and threatened species, and some rare natural habitat types which are protected in their own right; network established by the European Union for the aim to ensure the long-term survival of Europe's most valuable and threatened species and habitats".

The first section gathered information about the respondents' habits with organic product purchase; specifically, it asked if the respondents are a member of solidaritybased purchasing groups and, if yes, the share of organic products buying through solidarity-based purchasing groups. The questionnaire is focused then on the respondent purchases of organic products examined: lentils.

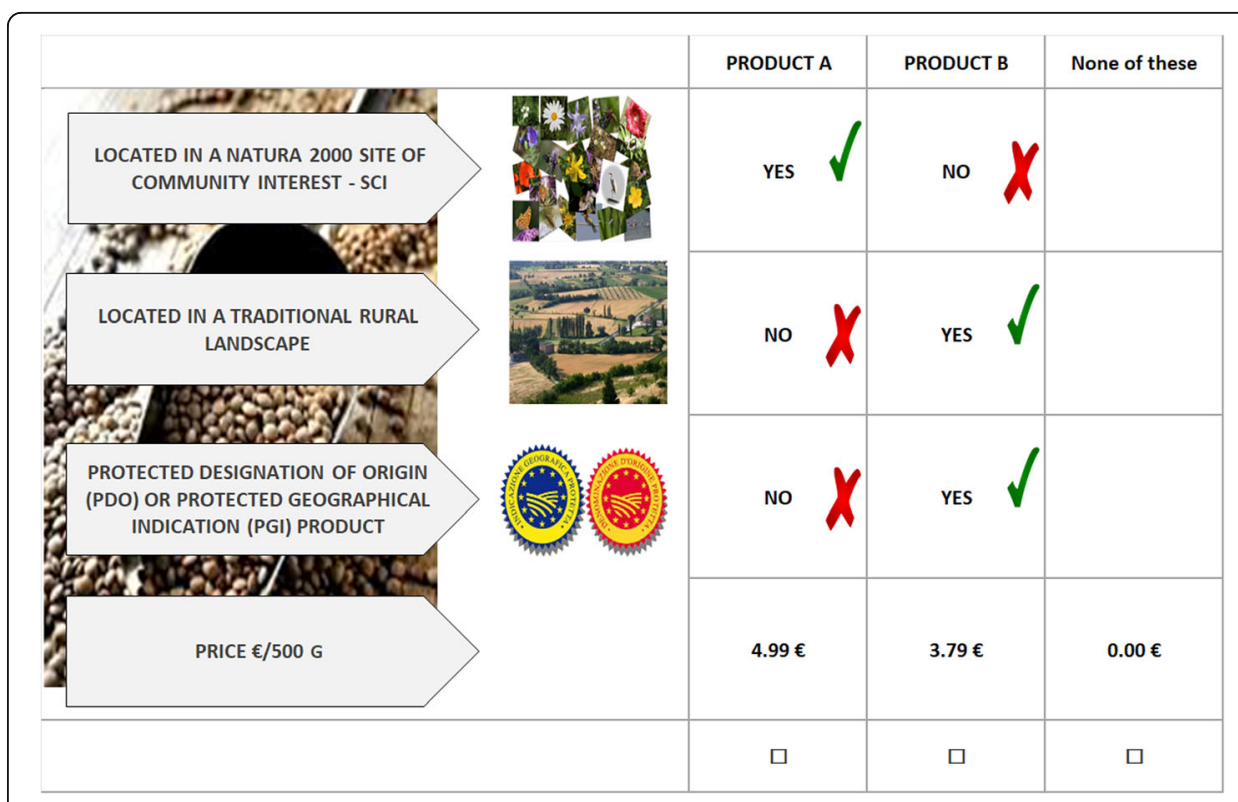

Fig. 1 Choice card example_organic lentils 
The second part focused on the choice experiment. After introducing the hypothetical scenario, we presented three lentil choice tasks to each respondent to facilitate them.

The last section of the questionnaire collected socio-economic information about the respondents (age, level of education, residence, gender, employment status, number of household members and standard of living).

\section{Sample and data collection}

Concerning the consumer sample choice, we focused on those that purchase through two O-SPGs, i.e. AFNs, because these types of supply chain are defined by several authors (Venn et al. 2006; Follet, 2009; Raffaelli et al. 2009; Sini 2009) as aimed at the dissemination of organic production methods, exchange and consumption that they pursue objectives of socio-economic and environmental sustainability as the health and quality of food, the protection of natural resources and biodiversity and the promotion of work and local culture.

Specifically, the two O-SPGs involved in our study are the two largest Organized Group of supply and demand (OGSD) present in Umbria managed in terms of logistics and organization by the Italian Association for Organic Agriculture (IAOA) and Organic Trade Association (OTA), both based on the collaborative relationship between producers and organic consumers (Viganò et al., 2012; Torquati et al., 2016).

Between March 2014 and April 2014, data were collected with a "web-based survey" in order to contact quickly the consumer sample selected (n. 682 members of the two O-SPGs). Specifically, we used Lime Survey, an open-source software application that allowed us to collect the data online. The survey software itself is self-guiding for the respondents who are participating. We managed to collect 213 completed questionnaires suitable for data analysis (more than $31 \%$ of response rate).

\section{Results}

\section{Sample characteristics and lentil consumption preferences}

The general overview of the socio-demographics of the people interviewed is presented in Table 2: of the 213 respondents, $67.6 \%$ were women and $49.7 \%$ were between the ages of 31 and 50. The interviewees have a high level of education: $50.2 \%$ hold a master's degree or $\mathrm{PhD}$ and $22.1 \%$ had earned a bachelor's degree while $26.3 \%$ hold a high school certification. More than $70 \%$ of the sample members were employed, while $12.2 \%$ were retirees and 5.2\% students. Housewives were a pronounced minority at $4.7 \%$. On average, most households were composed of three or four members (55.9\%), while singles or couples without children accounted for $36.6 \%$ of respondents. In $22.57 \%$ of cases, the household had 1,2 or 3 children under 7 years of age, while in $19.2 \%$ the household had 1, 2 or 3 children between 8 and 14 years of age. In $17.8 \%$ of the households, the members were seniors (aged 65 and over).

Most respondents lived in urban areas (70.4\%) while $29.6 \%$ of them lived in rural areas, either in villages or isolated houses.

In general, the average profile of the organic consumer's sample interviewed confirms what was also described in other studies (Hughner et al., 2007; de Magistris and Gracia, 
Table 2 Interviewee characteristics

\begin{tabular}{|c|c|c|c|c|c|}
\hline & Number & Percentage & & Number & Percentage \\
\hline Gender & & & Family members & & \\
\hline Female & 144 & 67.6 & Children (0-7 years) & 48 & 22.5 \\
\hline Male & 69 & 32.4 & Youth (8-14 years) & 41 & 19.2 \\
\hline Age & & & Elderly (65 or >) & 38 & 17.8 \\
\hline $20-30$ & 19 & 8.9 & Place of residence & & \\
\hline $31-40$ & 48 & 22.5 & Urban area—centre & 71 & 33.3 \\
\hline $41-50$ & 58 & 27.2 & Urban area_periphery & 79 & 37.1 \\
\hline $51-60$ & 59 & 27.7 & Rural area—village & 26 & 12.2 \\
\hline$>60$ & 29 & 13.6 & Rural area-isolated house & 37 & 17.4 \\
\hline Educational level & & & Association membership & & \\
\hline Middle school certification & 3 & 1.4 & Environmental & 163 & 76.5 \\
\hline High school certification & 56 & 26.3 & Cultural & 123 & 57.7 \\
\hline Bachelor's degree & 47 & 22.1 & Consumers & 163 & 76.5 \\
\hline \multirow[t]{3}{*}{ Master degree or PhD } & 107 & 50.2 & Volunteering & 167 & 78.4 \\
\hline & & & Sport & 159 & 74.6 \\
\hline & & & No association & 3 & 1.4 \\
\hline Occupation & & & Family income & & \\
\hline Employed & 150 & 70.4 & $<10,000 €$ & 13 & 6.1 \\
\hline Unemployed & 16 & 7.5 & Between 10,001 and $30,000 €$ & 86 & 40.4 \\
\hline Retired & 26 & 12.2 & Between 30,001 and $50,000 €$ & 58 & 27.2 \\
\hline Housewife & 10 & 4.7 & $>50,000 €$ & 23 & 10.8 \\
\hline Student & 11 & 5.2 & Not responded & 33 & 15.5 \\
\hline \multicolumn{6}{|l|}{ Household size } \\
\hline $1-2$ & 78 & 36.6 & & & \\
\hline $3-4$ & 119 & 55.9 & & & \\
\hline 5 and over & 16 & 7.5 & & & \\
\hline
\end{tabular}

2008; Annunziata \& Vecchio, 2016): she is a woman, with a high education level, aged between 31 and 50 and she mostly lives in urban areas.

Many were involved in some kind of volunteer association (78.4\%), environmental association (76.5\%) and consumer association. Only 3 respondents were not involved in no-one association.

With regard to household earnings, $40.2 \%$ of respondents declared an income between 10,001 and $30,000 €$ and $27.2 \%$ indicated it between 30,001 and 50,000 while $10.8 \%$ declared it over $50,000 €$.

The average monthly household spending of interviewees on food was $€ 371.64$, of which $48.55 \%$ was made up of purchases of organic products.

Specifically, it was asked to the respondents also whether they belonged to an SPG: $55.87 \%$ of the respondents are SPG members, since 4 years on average, and they bought $57.46 \%$ of organic food through SPG.

Of the 213 respondents, $69.95 \%$ of them said that they buy them once a week, while $14.08 \%$ buys organic products once every 2 weeks. The consumers' occasional rate (who buy organic products "not regularly and less than once a month") was low (4.23\%). 
The organic products most purchased by respondents were mainly fruits, vegetables, grains, legumes and eggs; secondly, they also bought dairy products, flour, pasta and baked products.

The interviewees were asked to rate the importance of various factors influencing their choice for buying organic products, with five possible answers ranging from "not important at all" to "highly important" (using a 5-item Likert scale) (Table 3). The factors that have the greatest impact on organic product purchase are buy healthy products $(4.48)^{3}$, protect the environment by reducing the environmental impact (4.38) and buy good products (4.35). Instead, the factors that are considered less influential are buy products handcrafted (3.69), buy products with social content (3.57) and buy for trend (1.12).

The interviewees were asked about their purchase behaviour of the lentils. Of the 213 respondents, $39.44 \%$ declared they buy lentils not regularly and less than once a month, while $31.92 \%$ usually purchases lentils once a month and $12.21 \%$ once every 3 weeks; 8 respondents affirmed that they do not usually buy this product. On average, the respondents bought $7 \mathrm{~kg} /$ year of lentils and $6 \mathrm{~kg}$ of these was organic.

\section{RPL model results}

The RPL model has a good interpretative capacity (adj. $R^{2} 0.24$ ) and a better performance compared to the MNL model. All estimated parameters are significant, considering a $1 \%$ significance level, and the price attribute has a negative sign as expected (the higher the price, the lower on average respondents' utility). The RPL model results confirm the presence of quite heterogeneous preferences among respondents (Table 4), given that the standard deviation of the 3 parameters assumed normally distributed results statistically significant. Looking at the kernel distributions of the individual estimated parameters (see the Appendix, Fig. 2), it emerged that they are multimodal, suggesting the presence of potential clusters of respondents that share the same preferences.

The analysis of the relative importance of the attributes highlights that respondents' choices, without considering the price attribute, were mainly influenced by the location of the production area in a traditional rural landscape, followed by the presence of an EU quality label (PDO or PGI).

The sample mean WTPs (Table 4) calculated for a 500-g pack of lentils by means of the RPL model reflect the relative importance of attributes and are $1.61 €$ for lentils produced in a traditional rural landscape, $1.55 €$ for lentils with a EU quality label and 0.90 $€$ for lentils produced in a Natura 2000 SCI.

\section{EAA model results}

Considering our control questions about stated ANA, we first looked at the descriptive statistics of how many attributes were considered by respondents (aggregate statistics of attendance), and it emerged that $50.7 \%$ of our respondents considered all 4 attributes "always or sometimes", 33.33\% of them considered 3 attributes and $12.7 \%$ of them considered 2 attributes while $3.3 \%$ of them considered 1 attribute. More specifically (Table 5), the attribute less considered (namely the most subject to ANA) was the location in a Natura 2000 SCI, followed by the

\footnotetext{
${ }^{3}$ Values in parentheses are calculated as an average on the Likert scale from 1 (minimum) to 5 (maximum).
} 
Table 3 Factors considered when buying organic products, with average scores from a 5-point scale (5 indicating strong agreement)

\begin{tabular}{lll}
\hline & Mean & Std. deviation \\
\hline Buy healthy products & 4.481 & 0.733 \\
Protect the environment by reducing the environmental impact & 4.386 & 0.757 \\
Buy good products & 4.357 & 0.733 \\
Protect biodiversity & 4.200 & 0.942 \\
Buy local products to reduce the supply chain & 4.090 & 0.828 \\
Ensure fair prices for farmers & 4.052 & 0.903 \\
Defend animal welfare & 4.043 & 0.882 \\
Buy local products to support local producers & 4.029 & 0.852 \\
Preserve the traditional agricultural landscape & 3.919 & 0.987 \\
Buy products with ethical content & 3.814 & 0.987 \\
Buy products handcrafted & 3.690 & 0.956 \\
Buy products with social content & 3.576 & 0.991 \\
Buy for trend & 1.129 & 0.388 \\
\hline
\end{tabular}

price attribute, the EU quality label (PDO or PGI) and the location in a traditional rural landscape that were never considered by $25.8 \%, 19.2 \%, 15 \%$ and $8.5 \%$ respectively.

Our statistics about the stated ANA justify the need to check the reliability of our estimates of the MNL and RPL models with an EAA model (Table 4).

In terms of adj. $R^{2}$, the EAA model has a good fit (0.25) and brings a slight improvement compared to the RPL model. Even in this case, the estimated coefficients are statistically significant at a 99\% level and the coefficient for the price attribute has a negative sign. According to the EAA model, $45 \%$ of the sample considered the location in a Natura $2000 \mathrm{SCI}$ attribute, $42 \%$ the EU quality label, $31 \%$ the price attribute and $19 \%$ the location in a traditional rural landscape attribute.

It is possible to notice that the mean probability of attendance statistics estimated by the EAA model differs by the stated attendance statistics reported in Table 5 if we consider the column "Always" in terms of frequency of attendance.

Looking at the relative importance of attributes, taking into consideration ANA introduces differences compared to the RPL results. The most important attribute is now the EU quality label (WTP $=1.90 €$ ), followed by the traditional rural landscape (WTP $=1.45 €$ ), while the less important attribute is the location in a Natura 2000 SCI (WTP $1.14 €$ ) for both models.

Comparing the WTPs estimated with the three models looking at the confidence intervals (Table 4) and at the $Z$-test results (see the Appendix, Table 6), it is possible to notice that they cannot be considered statistically different considering a $95 \%$ probability. Despite the mean WTPs are not statistically different between the RPL and EAA model, it should be considered that mean WTPs are usually considered in driving conclusions from DCE results. In this respect, just looking at the mean WTPs of the RPL model that do not consider ANA (ANA is taken into account by the EAA model estimates) would lead in an overestimation of WTP in one case (located in a traditional rural landscape, $+11 \%=[(1.61-1.45)$ / 
Table 4 DCE model results

\begin{tabular}{|c|c|c|c|c|c|c|c|}
\hline & \multicolumn{2}{|l|}{ MNL } & \multicolumn{2}{|l|}{$\mathrm{RPL}^{\circ}$} & \multicolumn{3}{|l|}{ EAA } \\
\hline & Coeff. & $\begin{array}{l}\text { WTP } \\
(€ / 500 \mathrm{~g})\end{array}$ & Coeff. & $\begin{array}{l}\text { WTP } \\
(€ / 500 \mathrm{~g})\end{array}$ & Coeff. & $\begin{array}{l}\text { WTP } \\
(€ / 500 \mathrm{~g})\end{array}$ & $\begin{array}{l}\text { Probability } \\
\text { of attendance }\end{array}$ \\
\hline \multirow[t]{2}{*}{ ASC } & $-3.23^{* * *}$ & & $-4.87^{* * *}$ & & $-6.33^{* * *}$ & & \\
\hline & {$[-4.02,-2.44]$} & & {$[-6.30,-3.44]$} & & {$[-8.35,-4.31]$} & & \\
\hline \multirow{2}{*}{$\begin{array}{l}\text { Located } \\
\text { in Natura } \\
2000 \mathrm{SCl}\end{array}$} & $0.79^{* * *}$ & 0.88 & $1.29^{* * *}$ & 0.9 & $2.14^{* * *}$ & 1.14 & $0.45^{* * *}$ \\
\hline & {$[0.54,1.03]$} & {$[0.63,1.13]$} & {$[0.78,1.80]$} & {$[0.59,1.21]$} & {$[1.13,3.15]$} & {$[0.67,1.60]$} & {$[0.20,0.69]$} \\
\hline \multirow{2}{*}{$\begin{array}{l}\text { Located in } \\
\text { a traditional } \\
\text { rural } \\
\text { landscape }\end{array}$} & $1.33^{* * *}$ & 1.49 & $2.31^{* * *}$ & 1.61 & $2.74^{* * *}$ & 1.45 & $0.19 * *$ \\
\hline & {$[1.08,1.58]$} & {$[1.19,1.79]$} & {$[1.70,2.92]$} & {$[1.27,1.94]$} & {$[1.94,3.53]$} & {$[1.10,1.81]$} & {$[0.04,0.34]$} \\
\hline \multirow{2}{*}{$\begin{array}{l}\text { EU quality } \\
\text { label } \\
\text { (PDO/PGI) }\end{array}$} & $1.44^{* * *}$ & 1.61 & $2.22^{* * * *}$ & 1.55 & $3.58^{* * *}$ & 1.9 & $0.42^{* * *}$ \\
\hline & {$[1.12,1.76]$} & {$[1.37,1.85]$} & {$[1.56,2.88]$} & {$[1.24,1.85]$} & {$[2.49,4.66]$} & {$[1.52,2.28]$} & {$[-0.29,0.54]$} \\
\hline \multirow{2}{*}{$\begin{array}{l}\text { Price } \\
(€ / 500 \mathrm{~g})\end{array}$} & $-0.90^{* * *}$ & & $-1.44^{* * *}$ & & $-1.88^{* * *}$ & & $0.31^{* * *}$ \\
\hline & {$[-1.09,-0.70]$} & & {$[-1.82,-1.05]$} & & {$[-2.46,-1.31]$} & & {$[0.18,0.44]$} \\
\hline \multicolumn{8}{|c|}{ Standard Deviation of Random Parameters Distribution } \\
\hline \multirow{2}{*}{$\begin{array}{l}\text { Located } \\
\text { in Natura } \\
2000 \text { SCl }\end{array}$} & & & $1.64^{* * *}$ & & & & \\
\hline & & & {$[0.97,2.31]$} & & & & \\
\hline \multirow{2}{*}{$\begin{array}{l}\text { Located in } \\
\text { a traditional } \\
\text { rural } \\
\text { landscape }\end{array}$} & & & $1.54^{* * *}$ & & & & \\
\hline & & & {$[0.89,2.19]$} & & & & \\
\hline \multirow{2}{*}{$\begin{array}{l}\text { EU quality } \\
\text { label } \\
\text { (PDO/PGI) }\end{array}$} & & & $2.07^{* * *}$ & & & & \\
\hline & & & {$[1.36,2.79]$} & & & & \\
\hline Observations & 1917 & & 1917 & & & 1917 & \\
\hline Respondents & 213 & & 213 & & & 213 & \\
\hline LL & $-560,376$ & & $-532,140$ & & & $-525,289$ & \\
\hline $\operatorname{adj} . R^{2}$ & 0.2018 & & 0.2420 & & & 0.2517 & \\
\hline AIC & 1130.75 & & 1080.28 & & & 1068.58 & \\
\hline$B / C$ & 1158.54 & & 1124.75 & & & 1118.60 & \\
\hline
\end{tabular}

$95 \%$ confidence intervals in brackets

${ }^{*} p<0.05,{ }^{* *} p<0.01,{ }^{* * *} p<0.001$

${ }^{\circ} 1000$ Halton draws, random parameters assumed normally distributed

$1.45] \times 100)$ and in an underestimation in 2 cases (located in Natura 2000 SCI, $-21 \%=$ $[(0.90-1.14) / 1.14] \times 100$, and EU quality label, $-18 \%=[(1.55-1.90) / 1.90] \times 100)$.

\section{Discussion and conclusions}

Consumer demand for food products with certain characteristics of the area of production could have an important role in indirectly strengthening the economic development of rural territory: an interesting example of this phenomenon could be pulses.

Currently, pulses (and as consequence lentils) are more and more becoming known as trendy food (Lemken et al., 2017) thanks to their several health and environmental benefits. As a result, the still low European and Italian consumption levels started to grow in the last years. This increase in internal demand per annum is leading to a gradual lentil cultivation growth. In this sense, it is important to remind that the Italian 
Table 5 Attendance statistics by attribute based on stated attribute attendance

\begin{tabular}{|c|c|c|c|c|c|c|c|}
\hline & \multicolumn{6}{|c|}{ Attribute attendance } & \multirow{3}{*}{$\begin{array}{l}\text { tot } \\
n\end{array}$} \\
\hline & \multicolumn{2}{|c|}{ Always } & \multicolumn{3}{|c|}{ Sometimes } & \multirow{2}{*}{$\begin{array}{l}\text { Never } \\
\%\end{array}$} & \\
\hline & $n$ & $\%$ & $n$ & $\%$ & $n$ & & \\
\hline Located in Natura 2000 SCl & 26 & 12.2 & 132 & 62.0 & 55 & 25.8 & 213 \\
\hline Located in a traditional rural landscape & 74 & 34.7 & 121 & 56.8 & 18 & 8.5 & 213 \\
\hline EU quality label (PDO/PGI) & 71 & 33.3 & 110 & 51.6 & 32 & 15.0 & 213 \\
\hline Price & 83 & 39.0 & 89 & 41.8 & 41 & 19.2 & 213 \\
\hline
\end{tabular}

organic lentil production is carried out frequently low-input or organic in rural marginal areas with particular rural landscape value, and in two cases, these productions have also been recognized by PGI EU quality labels. All these elements are related to rural sustainability, and this product could represent one of the drivers for the rural territories where lentils are cultivated precisely because these values are recognized by organic consumers as demonstrated by the results of this work.

This study highlighted how traditional rural landscape, quality label and environmental quality play a significant role in organic consumer behaviour who are willing to pay a premium price for them. Our results are crucial for understanding the importance in monetary terms of the relationship between lentil choice and rural sustainability.

Results reveal that the most important attribute affecting the interviewees' propensity to pay a premium price to buy organic lentils is the EU quality label according to the EAA model (willingness to pay $1.90 € / 500 \mathrm{~g}$ ), while it is the traditional rural landscape in the RPL model (willingness to pay $1.61 € / 500 \mathrm{~g}$ ). These results confirm that the PGI EU quality label is particularly crucial for fringe or fragile areas (Colinet et al., 2006) where the agricultural technique intensification would not be possible and valid and where the PGI EU quality label could be a presidio against abandon of these rural areas and a tool of producing premium prices that can support productions and economic activities (Barjolle et al., 2011).

One important aspect highlighted is the mutually beneficial relationship between the consumption of organic lentils and the preservation of the traditional rural landscape. The WTP of $1.61 € / 500 \mathrm{~g}$ of lentils in the RPL model, or of $1.45 € / 500 \mathrm{~g}$ of lentils in the EAA model, demonstrates that traditional rural landscape preservation through the lentil cultivation can be a driver of rural development because it can improve farm income and consequently the resilience of farms in a marginal territory, as already stated in previous works (Paquette and Domon, 2003; Domon, 2011; Tempesta, 2019; Torquati et al., 2015; Gullino, 2018; Torquati et al., 2018).

Starting to the concept that the consumer perception towards landscape features of food production is linked to different cultural backgrounds, factors and emotional values (Tempesta et al., 2010), we may affirm that the influence of landscape attribute on consumer behaviours is strictly connected to the product and the agricultural system where it is produced (in terms of intensive/extensive) (Cosmina et al., 2016). In a recent study on extra-virgin olive oil purchase, the results underlined that a specific market segment of people (that usually buy olive oil at the supermarket) is willing to pay more for olive oil obtained from olive trees cultivated in a traditional rural 
landscape (WTP of $2.95 € / 1$ for EVOO) (Tempesta and Vecchiato, 2019), while Cosmina et al. (2016) analysing the honey consumer demand demonstrated that the production obtained in a traditional well-preserved landscape attribute influenced only a small group of consumers in terms of WTP.

From our results, the presence of ANA had an impact on both the relative importance of the estimated attributes and the magnitude of the estimated mean WTP. Looking at the estimated probability of attendance, we found that our EAA estimates differ from the stated attribute attendance by respondents. A similar result was found from Caputo et al. (2018) comparing endogenous (inferred) ANA probabilities and serial stated attendance. Looking at the estimated mean WTPs, we found some discrepancies between the estimates of the three models. The same was found by other authors (Hensher \& Greene, 2010; Hole, 2011; Scarpa et al., 2009), suggesting that ANA should not be neglected during data analysis in order to avoid biased estimates. It is interesting to look at Hole (2011) results given that he applied the same EAA model used in our paper. The author found that its estimates were lower compared to MNL estimates for 4 attributes out of 5 ; in our DCE, we found nearly the opposite, with the EAA model overestimating WTPs for 2 attributes out of 3 both compared to the MNL and RPL models.

A further result is that in our case the estimated WTPs of the RPL and EAA models could not be considered statistically different (it should be noted that the estimated confidence intervals are quite wide). Mean estimates should, therefore, be considered with caution for marketing purposes, and taking the estimated mean WTPs of the 3 models (without considering their confidence intervals) would lead to differences in the mean WTPs that have a minimum magnitude of $11 \%$ and a maximum magnitude of $23 \%$ in absolute terms (considering the RPL and EAA results). In this respect, neglecting ANA and just using a standard RPL model would have introduced an error in mean estimates of a maximum of $23 \%$ in our case.

The statistical-descriptive analysis of the participants to the survey has highlighted a complex and evolved consumer figure, above all if we consider that this study was carried out in a general context of international economic crisis and, as a consequence, of erosion of the families' purchasing power that is characterizing this decade's end, above all in Italy. These outcomes highlight the consumer sensibility in terms of responsibility and awareness of the productions' impact on the environment, as highlighted in other studies (Briamonte, Giuca, 2010; Hughner et al., 2007; Pearson et al., 2011; Oates et al., 2012; de Magistris and Gracia, 2008). Our results, as stated also by several authors (Gullino et al., 2018; Belletti et al., 2015), showed that connecting rural landscape with food highquality products (PGI/PDO) should be regarded as having high important potential and value for rural areas in terms of preservation and development.

In particular, considering the GI propensity to function as "the reproduction of local resources" (FAO, 2011) in terms of territorial, natural and cultural value preservation, it is fundamental that local stakeholders involved take into consideration the information and tools for their future assessments and decision making. In this sense, producers should orient towards sustainable development of production areas considering overexploitation of natural and human resources could damage the GI system itself and its viability from one side, and from another side, the 
sustainability of the products is increasingly demanded by consumers and it is becoming an essential condition for market access (Vandecandelaere et al., 2018).

Another important aspect, although Natura 2000 SCI is the less important attribute (willingness to pay $1.14 € / 500 \mathrm{~g}$ in the EAA model and $0.59 € / 500 \mathrm{~g}$ in the RLP model), highlighted how the conservation of nature could have consistent positive repercussions for economic activities in Nature 2000 Sites. In fact, previous searches have shown how farms in Natura 2000 Sites can be not only viable but also competitive (Kettunen et al. 2009; European Commission, 2013).

The results of this work suggest the need to communicate the value of pulses (Belletti et al., 2017b) and, in particular, of lentils to consumers (Lemken et al., 2017). In fact, considering both the lack of publicity and modern marketing strategies focusing on pulses, as some researchers have underlined (Klemcke et al., 2013; Lemken et al., 2017), the trend in the lentils' consumption could change if advertising about the lentils will be addressed towards ecological, sustainable and quality matters added to human health advantage information. As a consequence, this marketing strategy could have a positive effect on lentil producers and their territories of production. These marketing strategies should be strictly connected to measures and activities needed to ensure improved productivity and high quality, so that pulses can be marketed, at local, regional and international levels, creating a valuable addition to farmer's incomes. In this way, the farmers could maintain their role in conserving and increasing the landscape's beauty and biodiversity in rural and marginal areas devoted to lentil cultivation.

Some limitations should be noted in this research. First is that the study was conducted in only one country (Italy) with 682 consumers-members of the two OSPGs; the response rate was more than $31 \%$. Even if O-SPGs are spreading in Italy, this model of AFNs is considered a niche market for organic products. However, we focused on O-SPGs because of their aim to support local producers and their products like are actually lentils for Umbrian rural areas. Second, the focus of this study was on organic lentils that have still both production and consumption little share, even if their market is gradually increasing. Thus, cautions must be applied as the findings from this study might not be generalizable to the entire population of Italian organic lentil consumers.

On the other hand, both the study's focus on a niche product and on such specific attributes limit the worries concerning the effect that the survey carried out 7 years ago could have on the validity and topicality of the results obtained. This statement is supported by the fact that at the end of 2021 a campaign to promote organic lentils will be launched based on a communication model resulting from the results obtained from this work.

All in all, if organic lentil consumption plays an important part in healthy human nutrition, food security, biodiversity and protection against the abandonment of the marginal rural areas, we should have a picture of that role as correct as possible. In this paper, we take some steps towards painting that picture. 


\section{Appendix}

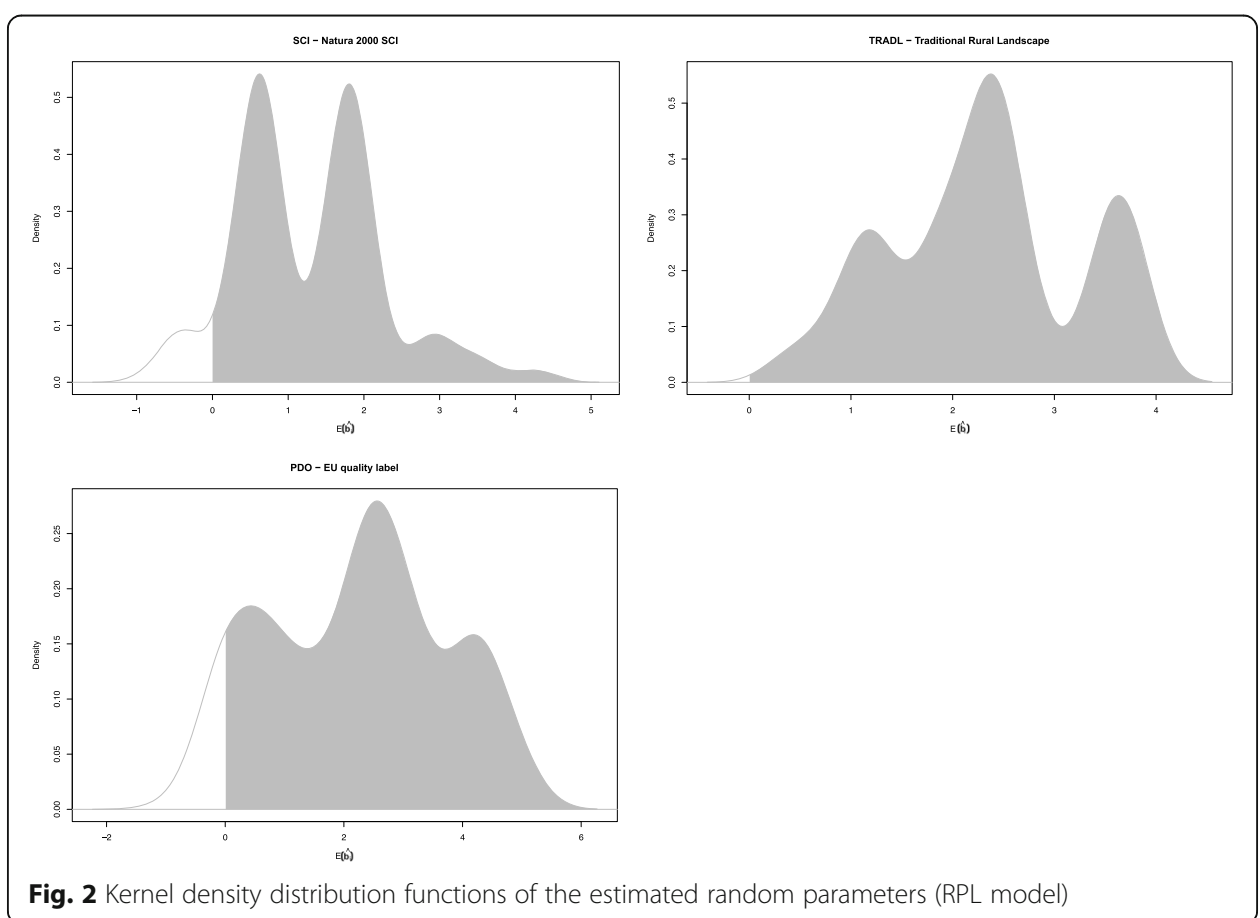

Table 6 Z-test (two-tailed) of equality of the estimated mean WTPs between models

\begin{tabular}{llll}
\hline & \multicolumn{2}{l}{ Model comparison } & \\
\cline { 2 - 4 } Attribute levels & RPL-MNL & EAA-MNL & EAA-RPL \\
\hline Located in Natura $2000 \mathrm{SCl}$ & Z-score & Z-score & Z-score \\
\hline Located in a traditional rural landscape & 0.098 & 0.965 & 0.842 \\
EU quality label (PDO/PGl) & 0.523 & -0.169 & -0.642 \\
\hline Zscore cal & -0.303 & 1.265 & 1.408 \\
\hline
\end{tabular}

$Z$-score critical value: $\mid Z$-score $\mid<1.96 ; a=5 \%$ 


\section{Acknowledgements}

The research on which this paper is based was undertaken as part of a research project "Enhancement of the traditional landscape for the sustainability of the rural economy in the Sites of Community Interest" co-financed by "Fondazione Cassa di Risparmio of Perugia", Project code 2013.0209.021.

\section{Authors' contributions}

C.P.: investigation, data curation, writing, reviewing and editing and visualization. B.T.: conceptualization, project administration, funding acquisition and supervision. T.T.: methodology and writing the original draft preparation. S.V.: investigation. D.V.: formal analysis, writing, reviewing and editing. The authors read and approved the final manuscript.

\section{Funding}

The research on which this paper is based was undertaken as part of a research project "Enhancement of the traditional rural landscape for the sustainability of the rural economy in the Natura 2000 Sites of Community Importance" co-financed by "Fondazione Cassa di Risparmio of Perugia" [Project code: 2013.0209.021].

\section{Availability of data and materials}

The datasets used and/or analysed during the current study are available from the corresponding author on reasonable request.

\section{Declarations}

\section{Ethics approval and consent to participate}

Not applicable

\section{Consent for publication}

Not applicable

\section{Competing interests}

The authors declare that they have no competing interests.

\section{Author details}

'Department of Agricultural, Food and Environmental Sciences, University of Perugia, Borgo XX Giugno 74, 06121

Perugia, Italy. ${ }^{2}$ Department of Land, Environment, Agriculture and Forestry, University of Padova, Campus di Agripolis, Viale dell'Università, 16, 35020 Legnaro, Padova, Italy.

Received: 7 November 2020 Revised: 9 May 2021

Accepted: 22 July 2021 Published online: 19 August 2021

\section{References}

Afshin A, Micha R, Khatibzadeh S, \& Mozaffarian D (2014) Consumption of nuts and legumes and risk of incident ischemic heart disease, stroke, and diabetes: a systematic review and meta-analysis. The American journal of clinical nutrition, 100(1), 278-288. https://doi.org/10.3945/ajcn.113.076901

Agnoletti M (Ed.) (2013) Italian historical rural landscapes. Cultural values for the environment and rural development. Springer, Dordrecht. https://doi.org/10.1007/978-94-007-5354-9

Annunziata A, \& Vecchio R (2016) Organic farming and sustainability in food choices: an analysis of consumer preference in Southern Italy. Agriculture and Agricultural Science Procedia, 8, 193-200. https://doi.org/10.1016/j.aaspro.2016.02.093

Antrop M (2005) Why landscapes of the past are important for the future. Landscape and Urban Planning 70: 21-34. https:// doi.org/10.1016/j.landurbplan.2003.10.002, 1-2

Ariyawardana A, Govindasamy R, Gunaratne LHP, \& Lisle A (2012) Sri Lankan consumer preference for red lentils: a conjoint approach. In 22nd Annual IFAMA World Forum and Symposium. International Food and Agribusiness Management Association.

Babcock BA, \& Clemens R (2004) Geographical indications and property rights: protecting value-added agricultural products, MATRIC. Briefing Paper 04-MBP 7, lowa State University.

Bardhi R, \& Kapaj I (2017) The contribution of geographical indications in sustainable rural development (evidence from northern Albania). European Journal of Business, Economics and Accountancy, Vol 5, No 6. ISSN2056-6018

Barham E (2002) Towards a theory of value-based labeling. Agriculture and Human Values. 19(4): 349-360. https://doi.org/ https://doi.org/10.1023/A:1021152403919

Barjolle D \& Sylvander B (2000). PDO and PGl products: market, supply chains and institutions. Final Report. Brussels.

Barjolle D, Reviron S, Sylvander B (2007) Création et distribution de valeur économique dans les filières de fromages AOP. Economies et sociétés 41(9):1507-1524

Barjolle D, Sylvander B \& Thévenod-Mottet E (2011) Public policies and geographical indications. In CAB International Labels of Origin for Food, pp. 92-105. CAB International. https://doi.org/10.1079/9781845933524.0092, 2011

Bastian O, Neruda M, Filipová L, Machová I, \& Leibenath M (2010). Natura 2000 sites as an asset for rural development: the German-Czech Ore Mountains Green Network Project. Journal of Landscape Ecology, 3(2), 41-58. https://doi.org/10.2478/ v10285-012-0026-z

Belletti G, \& Marescotti A (2011) Origin products, geographical indications and rural development. Labels of Origin for Food. Local development, global recognition, 75-91. https://doi.org/10.1079/9781845933524.0075

Belletti G, Marescotti A, Sanz-Cañada J, \& Vakoufaris H (2015) Linking protection of geographical indications to the environment: evidence from the European Union olive-oil sector. Land Use Policy, 48, 94-106. https://doi.org/10.1016/j.la ndusepol.2015.05.003 
Belletti G, Marescotti A \& Brazzini A (2017a) Old world case study: the role of protected geographical indications to foster rural development dynamics: the case of Sorana Bean PGI. In The importance of place: geographical indications as a tool for local and regional development (pp. 253-276). Springer, Cham. https://doi.org/10.1007/978-3-319-53073-4_10

Belletti G, Marescotti A, \& Touzard JM (2017b) Geographical indications, public goods, and sustainable development: the roles of actors' strategies and public policies. World Development, 98, 45-57. https://doi.org/10.1016/j.worlddev.2015.05.004

Bello M, \& Abdulai A (2016) Impact of ex-ante hypothetical bias mitigation methods on attribute non-attendance in choice experiments. American Journal of Agricultural Economics, 98(5), 1486-1506. https://doi.org/10.1093/ajae/aav098

Ben-Akiva M, McFadden D \& Train K. (2019) Foundations of stated preference elicitation: consumer behavior and choicebased conjoint analysis. Foundations and Trends ${ }^{\circledast}$ in Econometrics, 10(1-2), 1-144. https://doi.org/10.1561/0800000036

Bérard L, Marchenay P (2006) Local products and geographical indications: taking account of local knowledge and biodiversity. Int. Soc. Sci. J. 187, 109-116, 58. https://doi.org/10.1111/j.1468-2451.2006.00592.x, 116

Bouchenak M \& Lamri-Senhadji M (2013) Nutritional quality of legumes, and their role in cardiometabolic risk prevention: a review. Journal of medicinal food, 16(3), 185-198. https://doi.org/10.1089/jmf.2011.0238

Bowen S (2008) Geographical indications: promoting local products in a global market. Madison, Wisconsin, USA, University of Wisconsin-Madison

Bowen S \& Zapata AV (2009) Geographical indications, terroir, and socioeconomic and ecological sustainability: the case of tequila. Journal of rural studies, 25(1), 108-119. https://doi.org/10.1016/j.jrurstud.2008.07.003

Bramley C \& Biénabe E (2013) Guidelines for selecting successful Gl products. In Developing geographical indications in the South (pp. 123-136). Springer, Dordrecht. https://doi.org/10.1007/978-94-007-6748-5_6

Briamonte L \& Giuca S (2010) Comportamenti e consumi socialmente responsabili nel sistema agroalimentare. Collana Studi sull'impresa, INEA, Roma, ISBN, 978-88.

Brown TC (2003) Introduction to stated preference methods. In A primer on nonmarket valuation; Champ, P.A.; Boyle, K.J.; Brown, T.C., Eds.; Springer Netherlands: Dordrecht, The Netherlands, pp. 99-110. https://doi.org/10.1007/978-94-007-0826$6+4$

Bryant C \& Granjon D (2009) Rural sustainability. In Sassen, S. (Ed.), Human settlement development, Encyclopedia of life support systems - Vol. 2 (pp. 158-191). Oxford: EOLSS Publishers/UNESCO. Retrieved from https://www.eolss.net/SampleChapters/C14/E1-18-04-00.pdf.

Buttel F (2006) Sustaining the unsustainable: agro-food systems and environment in the modern world. In: Cloke P, Marsden T, Mooney P (eds) Handbook of rural studies. SAGE Publications Ltd, London, UK. https://doi.org/10.4135/9781848608016. n15

Calles T (2016) The International Year of Pulses: what are they and why are they important. Agriculture for Development 26: 40-42

Camaioni C, D'Onofrio R, Pierantoni I \& Sargolini M (2016) Vineyard landscapes in Italy: cases of territorial requalification and governance strategies. Landscape Research, 41(7), 714-729. https://doi.org/10.1080/01426397.2016.1212323

Cantillo J, Martín JC \& Román C (2020) Discrete choice experiments in the analysis of consumers' preferences for finfish products: a systematic literature review. Food Quality and Preference, 103952. https://doi.org/10.1016/j.foodqual.2020.103 952

Caputo V, Nayga Jr RM, \& Scarpa R (2013) Food miles or carbon emissions? Exploring labelling preference for food transport footprint with a stated choice study. Australian Journal of Agricultural and Resource Economics, 57(4), 465-482. https:// doi.org/10.1111/1467-8489.12014

Caputo V, Van Loo EJ, Scarpa R, Nayga RM Jr, Verbeke W (2018) Comparing serial, and choice task stated and inferred attribute non-attendance methods in food choice experiments. Journal of Agricultural Economics 69(1):35-57. https://doi. org/10.1111/1477-9552.12246

Carpio CE \& Isengildina-Massa O (2009) Consumer willingness to pay for locally grown products: the case of South Carolina. Agribusiness, 25(3), 412-426. https://doi.org/10.1002/agr.20210

CBI (2015) Product Factsheet: Dried lentils in Europe, https:/www.cbi.eu/sites/default/files/market_information/researches/ product-factsheet-europe-dried-lentils-grains-pulses-2015.pdf (last access on 20.06.2017).

Claval P (2005) Reading the rural landscapes. Landscape and urban planning, 70(1-2), 9-19. https://doi.org/10.1016/j.la ndurbplan.2003.10.014

Colinet P, Desqilibet M, Hassan D, Monier-Dilhan S, Orozco V, Réquillart V (2006) Case study: Comté cheese in France. In: Prepared for EU-DG JRC/PTS. University of Toulouse, Toulouse, France, INRA

Confagricoltura (2016) Produzione e commercio dei legumi in Italia e nel Mondo, Centro studi Confagricoltura Confagricoltura Alessandria (http://www.confagricolturalessandria.it/comunicazione/centrostudi2.asp?id=520165444154 044) (last access on 13/11/2017)

Cosmina M, Gallenti G, Marangon F \& Troiano S (2016) Reprint of "Attitudes towards honey among Italian consumers: a choice experiment approach". Appetite, 106: 110-116. https://doi.org/10.1016/j.appet.2016.08.005

Curran J, McLachlan M, Black R, Widders I \& Manary M (2017). Collaboration among sectors to increase pulse consumption. Annals of the New York Academy of Sciences, 1392(1), 3-5. https://doi.org/10.1111/nyas.13321

Darby K, Batte MT, Ernst S \& Roe B (2008). Decomposing local: a conjoint analysis of locally produced foods. American Journal of Agricultural Economics, 90(2), 476-486. https://doi.org/10.1111/j.1467-8276.2007.01111.x

Darnhofer I (2015) Socio-technical transitions in farming. Key concepts. In: Sutherland, L-A., Darnhofer, I., Wilson, G.A. and Zagata, L. (eds) Transition pathways towards sustainability in agriculture: case studies from Europe. CABI, Wallingford, UK, pp. 17-32. https://doi.org/10.1079/9781780642192.0017

David C, Jeuffroy MH, Henning J, Meynard JM (2005) Yield variation in organic winter wheat: a diagnostic study in the Southeast of France. Agron Sustain Dev 25(2):213-223. https://doi.org/10.1051/agro:2005016

De Magistris T and Gracia A (2008) The decision to buy organic food products in Southern Italy. British Food Journal, 110(9): 929-947. https://doi.org/10.1108/00070700810900620

Domon G (2011) Landscape as resource: consequences, challenges and opportunities for rural development. Landscape and Urban Planning, 100(4), 338-340. https://doi.org/10.1016/j.landurbplan.2011.02.014

European Commission (2013) The economic benefits of the Natura 2000 Network. EC, Luxembourg. URL https://ec.europa.eu/ environment/nature/natura2000/financing/docs/ENV-12-018_LR_Final1.pdf. (last accessed on 10 Nov 2019). 
European Commission (2018) Managing farmland in Natura 2000. Case studies. Technical Report - 2018 - 002. URL https://ec. europa.eu/environment/nature/natura2000/management/docs/Farmland_Annex-E_WEB_en.pdf (last accessed on 15 Dec 2019).

Eurostat (2017) Dry pulses in EU agriculture - statistics on cultivation, production and economic value. http://ec.europa.eu/ eurostat/statistics-explained/index.php/Dry_pulses_in_EU_agriculture___statistics_on_cultivation,_production_and_ economic_value\#Further_Eurostat_information. (last access on 24.11.2018).

Eurostat (2020) World Pulses Day: production of pulses in the EU. https://ec.europa.eu/eurostat/web/products-eurostatnews/-/EDN-20200210-1. (last access on 22.04.2021).

FAO (2011) Identification of origin-linked products and their potential for development: a methodology for participatory inventories. Rome. http://www.fao.org/docrep/013/i1760e/i1760e.pdf. (last accessed on 15.07.2019).

FAO (2019) The global of economy pulses. Food and Agriculture Organization of the United. Nations, Rome, Italy

FAOSTAT (2016) FAOSTAT Statistics Database. Food and Agriculture Organization of the United. Nations, Rome, Italy

FAOSTAT (2018) FAOSTAT Statistics Database. Food and Agriculture Organization of the United. Nations, Rome, Italy

FAOSTAT (2020) FAOSTAT Statistics Database. Food and Agriculture Organization of the United. Nations, Rome, Italy

Gilovich T, Griffin D \& Kahneman D (2002) Heuristics and biases: the psychology of intuitive judgment. New York, NY, US: Cambridge University Press. https://doi.org/10.1017/CBO9780511808098

Giovannucci D, Josling TE, Kerr W, O'Connor B \& Yeung MT (2009) Guide to geographical indications: linking products and their origins (p. 232). Geneva: International trade centre. https://doi.org/10.2139/ssrn.1736713

Giraud KL, Bond CA \& Bond JJ (2005) Consumer preferences for locally made specialty food products across northern New England. Agricultural and Resource Economics Review, 34(2), 204. https://doi.org/10.1017/S1068280500008364, 216

Govindasamy R, Arumugam S, Vellangany I (2014) The influence of country-of-origin labeling for lentils on consumer preference: a study with reference to Sri Lanka. IUP J Marketing Manag 13(3):31

Gracia A (2014) Consumers' preferences for a local food product: a real choice experiment. Empirical Economics, 47(1), 111 128. https://doi.org/10.1007/s00181-013-0738-x

Guerra JL (2004) Geographical indications and biodiversity: bridges joining distant territories. Bridges 8(2):17-18

Gullino P, Devecchi M, \& Larcher F (2018) How can different stakeholders contribute to rural landscape planning policy? The case study of Pralormo municipality (Italy). Journal of Rural Studies, 57, 99-109. https://doi.org/10.1016/j.jururstud.2017.12.002

Hauber AB, González JM, Groothuis-Oudshoorn CG, Prior T, Marshall DA, Cunningham C ... \& Bridges JF (2016) Statistical methods for the analysis of discrete choice experiments: a report of the ISPOR Conjoint Analysis Good Research Practices Task Force. Value in health, 19(4), 300-315. https://doi.org/10.1016/j.jval.2016.04.004

Hebert M (2011) Examining current research on local food: a review. Studies by Undergraduate Researchers at Guelph, 4(2), 88-92. https://doi.org/10.21083/surg.v4i2.1251

Hensher DA \& Greene WH (2010) Non-attendance and dual processing of common-metric attributes in choice analysis: a latent class specification. Empirical Economics, 39(2), 413-426. https://doi.org/10.1007/s00181-009-0310-x

Hensher DA, Rose JM \& Greene WH (2005) Applied choice analysis: a primer. Cambridge University Press. https://doi.org/10.1 017/CBO9780511610356

Hensher DA, Rose JM \& Greene WH (2012) Inferring attribute non-attendance from stated choice data: implications for willingness to pay estimates and a warning for stated choice experiment design. Transportation, 39(2), 235-245. https:// doi.org/10.1007/s11116-011-9347-8

Hoek AC, Pearson D, James SW, Lawrence MA \& Friel S (2017) Shrinking the food-print: a qualitative study into consumer perceptions, experiences and attitudes towards healthy and environmentally friendly food behaviours. Appetite, 108, 117-131. https://doi.org/10.1016/j.appet.2016.09.030

Hole AR (2007) Fitting mixed logit models by using maximum simulated likelihood. Stata Journal, 7(3), 388-401. Retrieved from http://www.stata-journal.com/article.html?article=st0133. https://doi.org/10.1177/1536867X0700700306

Hole AR (2011) A discrete choice model with endogenous attribute attendance. Economics Letters, 110(3), 203-205. https:// doi.org/10.1016/j.econlet.2010.11.033

Howley P, Hynes S \& Donoghue CO (2012) Countryside preferences: exploring individuals' willingness to pay for the conservation of the traditional farm landscape. Landscape Research, 37(6), 703-719. https://doi.org/10.1080/01426397.2 011.637619

Hughner RS, McDonagh P, Prothero A, Shultz CJ \& Stanton J (2007) Who are organic food consumers? A compilation and review of why people purchase organic food. Journal of consumer behaviour, 6(2-3), 94-110. https://doi.org/10.1002/ $\mathrm{cb} .210$

Jensen E, Peoples M, Boddey R, Gresshoff P, Hauggaard-Nielsen H, Alves BJR, Morrison M (2012) Legumes for mitigation of climate change and the provision of feedstock for biofuels and biorefineries. A review. Sustain Dev. 32:329-364. https:// doi.org/10.1007/s13593-011-0056-7, 2

Joshi PK \& Rao PP (2016) Global and regional pulse economies: current trends and outlook (Vol. 144). Intl Food Policy Res Inst.

Kettunen M, Bassi S, Gantioler S \& ten Brink P (2009) Assessing socio-economic benefits of Natura 2000 - a toolkit for practitioners (September 2009 Edition). Output of the European Commission project Project Financing Natura 2000: Cost estimate and benefits of Natura 2000 (Contract No:: 070307/2007/484403/MAR/B2). Institute for European Environmental Policy (IEEP), Brussels, Belgium. 191 pp. + Annexes.

Klemcke S, Glende S, Rohn S (2013) The revitalisation of native grain legumes. Survey on buying habits and assessment if image of legumes. Ernaehrungs Umschau international 60(4):52-58

Lamarque P \& Lambin EF (2015) The effectiveness of marked-based instruments to foster the conservation of extensive land use: the case of Geographical Indications in the French Alps. Land Use Policy, 42, 706-717. https://doi.org/10.1016/j.la ndusepol.2014.10.009

Lancaster KJ (1966) A new approach to consumer theory. Journal of Political Economy, 74(2), 132. https://doi.org/10.1086/2 59131,157

Larson J (2007) Relevance of geographical indications and designations of origin for the sustainable use of genetic resources. Rome.

Lemken D, Knigge M, Meyerding S \& Spiller A (2017) The value of environmental and health claims on new legume products: a non-hypothetical online auction. Sustainability, 9(8), 1340. https://doi.org/10.3390/su9081340 
Loureiro ML \& Hine S (2002) Discovering niche markets: a comparison of consumer willingness to pay for local (Colorado grown), organic, and GMO-free products. Journal of Agricultural and Applied Economics, 34(3), 477-488. https://doi.org/1 $0.1017 / 51074070800009251$

Louviere JJ, Hensher DA, Swait JD, \& Adamowicz W (2000) Stated choice methods by Jordan J. Louviere [WWW Document]. Cambridge Core. https://doi.org/10.1017/CBO9780511753831

Luce RD (1959) Individual choice behavior: a theoretical analysis. Wiley, New York

Magnaghi A (2010) II progetto degli spazi aperti per la costruzione della bioregione urbana. Patto città campagna. Un progetto di bioregione urbana per la Toscana centrale, 35-64.

Magrini MB, Anton M, Chardigny JM, \& Duc G (2018) Pulses for sustainability: breaking agriculture and food sectors out of lock-in. Frontiers in Sustainable Food Systems, 2, 64. https://doi.org/10.3389/fsufs.2018.00064

Marian L, Chrysochou P, Krystallis A, \& Thøgersen J (2014) The role of price as a product attribute in the organic food context: an exploration based on actual purchase data. Food Quality and Preference, 37, 52-60. https://doi.org/10.1016/j. foodqual.2014.05.001

Marlett JA, McBurney MI \& Slavin JL (2002) Position of the American Dietetic Association: health implications of dietary fiber. Journal of the American Dietetic Association, 102(7), 993-1000. https://doi.org/10.1016/S0002-8223(02)90228-2

Marques F, van der Ploeg JD and Dal Soglio F (2012) New identities, new commitments: something is lacking between niche and regime. In: Barbier, M. and Elzen, B. (eds) System innovations, knowledge regimes and design practices towards transitions for sustainable agriculture. INRA - Science for Action and Development, pp. 23-46.

McFadden D (1974) Conditional logit analysis of qualitative choice behavior. In: Zarembka P (ed) Frontiers in econometrics. New York, Academic Press, pp 105-142

Oates L, Cohen M \& Braun L (2012) Characteristics and consumption patterns of Australian organic consumers. Journal of the Science of Food and Agriculture, 92(14), 2782-2787. https://doi.org/10.1002/jsfa.5664

Ortega DL, Wang HH, Wu L \& Olynk NJ (2011) Modeling heterogeneity in consumer preferences for select food safety attributes in China. Food Policy, 36(2), 318-324. https://doi.org/10.1016/j.foodpol.2010.11.030

Paquette S, Domon G (2003) Changing ruralities, changing landscapes: exploring social recomposition through a multi-scale approach. J. Rural Stud. 19, 425 - 444. https://doi.org/https://doi.org/10.1016/S0743-0167(03)00006-8, 4

Pearson D, Henryks J \& Jones H (2011) Organic food: what we know (and do not know) about consumers. Renewable Agriculture and Food Systems, 26(2), 171-177. https://doi.org/https://doi.org/10.1017/S1742170510000499

Peneva M, Draganova M, Gonzalez C, Diaz M and Mishev P (2015) High nature value farming: environmental practices for rural sustainability. In: Sutherland, L-A., Darnhofer, I., Wilson, G.A. and Zagata, L. (eds) Transition pathways towards sustainability in agriculture: case studies from Europe. CABI, Wallingford, UK, pp. 97-112. https://doi.org/10.1079/9781 780642192.0097

Piergiovanni AR (2000) The evolution of lentil (Lens culinaris Medik) cultivation in Italy and its effects on the survival of autochthonous populations. Genetic Resources and Crop Evolution, 47(3), 305-314. https://doi.org/10.1023/A:1 008789614680

Raffaelli R, Coser L, Gios G (2009) Esperienze di Filiera corta nell'agroalimentare: un'indagine esplorativa in provincia di Trento. Economia Agro Alimentare, n. 1:25-42

Rangnekar D (2004) The socio-economics of geographical indications: a review of empirical evidence from Europe. URL http://www.iprsonline.org/unctad/docs/CS_Rangnekar2.pdf (last access on accessed on 05 Jan 2019).

Riccheri M, Görlach B, Schlegel S, Keefe H and Leipprand A (2007) Assessing the applicability of geographical indications as a means to improve environmental quality in affected ecosystems and the competitiveness of agricultural products. WP3, IPDEV Project, Impacts of the IPR Rules on Sustainable Development, European Commission, Sixth Framework Programme: $125 \mathrm{p}$.

Roe M (2016) Editorial: food and landscape, Landscape Research, 41:7, 709-713. https://doi.org/https://doi.org/10.1080/014263 97.2016.1226016

Rose JM, \& Bliemer MCJ (2009) Constructing efficient stated choice experimental designs. Transport Reviews, 29(5), 587-617. https://doi.org/10.1080/01441640902827623, 29, 5, 587, 617

Scarpa R, Gilbride TJ, Campbell D, Hensher DA (2009) Modelling attribute non-attendance in choice experiments for rural landscape valuation. European Review of Agricultural Economics 36(2):151-174. https://doi.org/10.1093/erae/jbp012

Scarpa R, Zanoli R, Bruschi V, Naspetti S (2013) Inferred and stated attribute non-attendance in food choice experiments. American Journal of Agricultural Economics 95(1):165-180. https://doi.org/10.1093/ajae/aas073

Sini MP (2009) Aspetti del dibattito sulla filiera corta. Agriregionieuropa, n. 16:1-11

Takruri HR, Issa AY (2013) Role of lentils (Lens culinaris L.) in human health and nutrition: a review. Mediterranean Journal of Nutrition and Metabolism 6(1):3-16. https://doi.org/10.3233/s12349-012-0109-8

Tempesta T (2019) Landscape and economy, in Sadovnikova E. et al., Sustainable territorial development and landscape. Scholar's Press, Riga (Latvia)

Tempesta T, Vecchiato D (2019) Analysis of the factors that influence olive oil demand in the Veneto region (Italy). Agriculture (Switzerland) 9(7). https://doi.org/10.3390/agriculture9070154

Tempesta T, Arboretti Giancristofaro R, Corain L, Salmaso L, Tomasi D, Boatto V (2010) The importance of landscape in wine quality perception: an integrated approach using choice-based conjoint analysis and combination-based permutation tests. Food Quality and Preferences 21(7):827-836. https://doi.org/10.1016/j.foodqual.2010.04.007

Tempesta T, Vecchiato D, Djumboung DA, Chinazzi G (2014) An analysis of the potential effects of the modification of the Prosecco Protected Designation of Origin: a choice experiment. International Agricultural Policy, n.2, pp.33-48.

Thurstone LL (1927) A law of comparative judgment. Psychological Review 34(4):273-286. https://doi.org/10.1037/h0070288

Torquati B, Giacchè G, Venanzi S (2015) Economic analysis of the traditional cultural vineyard landscapes in Italy. Journal of rural studies 39:122-132. https://doi.org/10.1016/j.jrurstud.2015.03.013

Torquati B, Viganò E, Taglioni C (2016) Construction of alternative food networks for organic products: a case study of "Organized Groups of Supply and Demand". New Medit 15(4):53-63

Torquati B, Tempesta T, Vecchiato D, Venanzi S \& Paffarini C (2017) The value of traditional rural landscape and nature protected areas in tourism demand: a study on agritourists' preferences. Landscape Online, 53. https://doi.org/10.3097/ LO.201753 
Torquati B, Tempesta T, Vecchiato D, Venanzi S (2018) Tasty or sustainable? The effect of product sensory experience on a sustainable new food product: an application of discrete choice experiments on Chianina Tinned Beef. Sustainability 10(8). https://doi.org/10.3390/su10082795

Train K (2009) Discrete choice methods with simulation (second ed.): Cambridge University Press.

Troiano S, Marangon F, Tempesta T, Vecchiato D (2016) Organic vs local claims: substitutes or complements for wine consumers? A marketing analysis with a discrete choice experiment. New Medit 15(2):14-21

Vakoufaris H (2010) The impact of Ladotyri Mytilinis PDO cheese on the rural development of Lesvos island, Greece. Local Environment 15(1):27-41. https://doi.org/10.1080/13549830903406057

Van Loo EJ, Caputo V, Nayga RM, Meullenet JF, Ricke SC (2011) Consumers' willingness to pay for organic chicken breast: evidence from choice experiment. Food Quality and Preference 22(7):603-613. https://doi.org/10.1016/j. foodqual.2011.02.003

Vandecandelaere E, Arfini F, Belletti G, Marescotti A, Allaire G, Cadilhon JJ ... \& Jull C (2009) Linking people, places and products. A guide for promoting quality linked to geographical origin and sustainable geographical indications. $F A O$

Vandecandelaere E, Teyssier C, Barjolle D, Jeanneaux P, Fournier S, Beucherie O (2018) Strengthening sustainable food systems through geographical indications. FAO, Rome

Venn L, Kneafsey M, Holloway L, Cox R, Dowler E, Tuomainen H (2006) Researching European 'alternative' food networks: some methodological considerations. Area 38(3):248-258. https://doi.org/10.1111/j.1475-4762.2006.00694.x

Viganò E, Mariani A, Taglioni C, \& Torquati B. (2012) Consumatori e canali alternativi per il biologico: il caso del Gruppo Organizzato di Domanda e Offerta di Aiab-Umbria. Economia Agro-Alimentare.

Warne T, Ahmed S, Byker Shanks C, Miller P (2019) Sustainability dimensions of a North American lentil system in a changing world. Front. Sustain. Food Syst. 3:88. https://doi.org/10.3389/fsufs.2019.00088

Williams R, Penker M (2009) Do geographical indications promote sustainable rural development? Aust Soc Agricult Eco 18(3)

Xipsiti M, Marzara S, Calles T (2017) International Year of Pulses: keeping the momentum beyond 2016. Nutrition Bulletin 42(4):346-350. https://doi.org/10.1111/nbu.12295

Zoll F, Specht K, Opitz I, Siebert R, Piorr A, Zasada I (2018) Individual choice or collective action? Exploring consumer motives for participating in alternative food networks. Int J Consum Stud 42(1):101-110. https://doi.org/10.1111/ijcs.12405

\section{Publisher's Note}

Springer Nature remains neutral with regard to jurisdictional claims in published maps and institutional affiliations.

\section{Submit your manuscript to a SpringerOpen ${ }^{\circ}$ journal and benefit from:}

- Convenient online submission

- Rigorous peer review

- Open access: articles freely available online

- High visibility within the field

Retaining the copyright to your article

Submit your next manuscript at $\boldsymbol{\nabla}$ springeropen.com 